\title{
EVALUATION OF UNIVERSAL EXTRACTANTS FOR DETERMINATION OF SELECTED MICRONUTRIENTS FROM SOIL
}

\author{
Mesfin Bibiso $^{1 *}$, Abi M.Taddesse ${ }^{2}$, Heluf Gebrekidan $^{1}$ and Asmare Melese ${ }^{3}$ \\ ${ }^{1}$ School of Natural Resources Management and Environmental Sciences, Haramaya University, \\ Ethiopia \\ ${ }^{2}$ College of Natural and Computational Sciences, Department of Chemistry, Haramaya \\ University, Ethiopia \\ ${ }^{3}$ College of Natural and Computational Sciences, Department of Chemistry, Debre Berhan \\ University, Ethiopia
}

(Received November 4, 2014; revised May 8, 2015)

\begin{abstract}
A study was carried out with the objective of identifying the most suitable universal extractant for determination of selected micronutrients from soils. Composite surface soil samples $(0-20 \mathrm{~cm})$ were collected from Eastern Harargie Zone (Babile and Haramaya Districts), Wolaita Zone (Damot Sore, Boloso Bombe, Damot Pulasa and Humbo Districts) and Dire Dawa Administrative Council by purposive sampling. The treatments were arranged in completely randomized design (CRD) with three replications at Haramaya University Soil Laboratory. The results showed that among the universal extractants examined for the determination of available $\mathrm{Fe}, \mathrm{Cu}$ and $\mathrm{Zn}$, the highest correlation coefficients $(\mathrm{r}=0.95),(\mathrm{r}=0.99)$ and $(\mathrm{r}=0.97)$ at $(\mathrm{p}<0.001)$ were found between DTPA and AB-DTPA for available $\mathrm{Fe}, \mathrm{Cu}$ and $\mathrm{Zn}$, respectively. Therefore, AB-DTPA universal extractant can easily be adopted as a soil testing method for the determination of available $\mathrm{Fe}, \mathrm{Cu}$ and $\mathrm{Zn}$ in some selected soils of Ethiopia. Similarly, the concentration of available Mn determined by DTPA method was significantly correlated with the amount determined by tested universal extractants. The highest correlation coefficients were found between DTPA and $0.01 \mathrm{M} \mathrm{CaCl}_{2}(\mathrm{r}=0.90)$, DTPA and $0.01 \mathrm{M} \mathrm{BaCl}_{2}(\mathrm{r}=0.87)$, DTPA and $0.02 \mathrm{M} \mathrm{SrCl}_{2}$ $(\mathrm{r}=0.86)$, DTPA and $0.1 \mathrm{M} \mathrm{BaCl}_{2}(\mathrm{r}=0.89)$ and DTPA and AB-DTPA $(\mathrm{r}=0.85)$. However, considering the use of universal extractant, AB-DTPA could be the most suitable universal extractant for the determination of available $\mathrm{Mn}$ in soils of the studied areas as well. Therefore, AB-DTPA extractant is considered to be superior and the most suitable universal extractant for determination of available $\mathrm{Fe}, \mathrm{Cu}, \mathrm{Mn}$ and $\mathrm{Zn}$ in soil of the studied areas.
\end{abstract}

KEY WORDS: Micronutrients, Multinutrient extractant, Soil testing method, Unbuffered salts

\section{INTRODUCTION}

Micronutrients are needful elements for normal growth of plants, that are needed at little amount [1]. If these elements are not available sufficiently, plants will suffer from physiological stresses that are caused by inefficiency of several enzymatic systems and other related metabolic functions. It is widely accepted that the behaviour of micronutrients in soils cannot be assessed by measuring only the total metal concentration. This is because of the complexity of metal ion dynamics in the soil system and the interactive role of plant and environmental factors on the whole process [2]. The deficiencies of micronutrients have become major restrictions to productivity, stability and sustainability of soils [3].

Soil testing is a proven diagnostic tool to estimate plant nutrient availability in soil. It is underutilized in the developing world because of lack of rapid and reliable soil testing procedures and related facilities [4]. Soil tests measure the quantity of nutrient element that is extracted from a soil by a particular chemical extracting solution. The measured quantity of extractable nutrient in a soil is then used to predict the crop yield response to application of the nutrient as a fertilizer, manure, or other amendments [5]. An assessment of the nutrient status in the soil using conventional method requires a separate extraction and measurement process for most elements; this is costly process in terms of both time and labour [6].

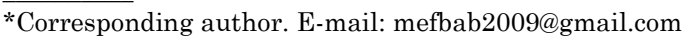


Universal soil extractant is the term that has been adopted to designate a reagent that can be used to extract more than one class of elements and/or ions from a soil with the concentration found being a means for assessing the soil's fertility status or levels of toxicity. The advantages of universal extractants in soil testing methods include increasing the reliability of soil test, increasing accuracy and precision of the tests and it saves time and increase the efficiency of the methods in routine soil analysis [7]. Several methodologies have been developed and introduced for rapid soil tests to determine the quantities of elements in soil for the last few years [8]. The advantages are significant in today's soil testing laboratories, one being the use of multi-element analyzers such as inductively coupled plasma (ICP) spectrometer and automated flow injection analyzers for assaying prepared soil extracts [9].

Various methods for micronutrient assessment in soils are available. These include dilute acids, chelating agents such as ethylene diamine tetra acetic acid (EDTA) and diethylenetriamine penta acetic acid (DTPA) [10, 11]. One of the major advances in micronutrient soil testing has been the development of extracting solutions that contain chelating agents, primarily DTPA and EDTA [12]. Mehlich 3 extractant was developed as a universal (multiple nutrients) extractant for routine analyses of micronutrients $(\mathrm{Cu}, \mathrm{Fe}, \mathrm{Mn}, \mathrm{Zn}$, etc.) for a wide range of soils across acidic, neutral and high $\mathrm{pH}$ soils in addition to macronutrients [13]. High correlation coefficients were found between values of $\mathrm{Zn}, \mathrm{Fe}, \mathrm{Mn}$ and $\mathrm{Cu}$ determined by TEA-DTPA and AB-DTPA [14]. Moreover, the AB-DTPA extractant was highly correlated with Mehlich 3 method for $\mathrm{Cu}$ and $\mathrm{Zn}$ determination [15].

The drive for targeting higher agricultural production needs a balanced use of nutrients which otherwise create problems of soil fertility exhaustion and nutrient imbalances not only of major but also of secondary and micronutrients. Crop yields may be limited by micronutrient deficiency caused by the low natural fertility of some soils, considerable nutrient removal by harvests and excessive application of phosphate fertilizers and substances for correction of soil acidity, causing the insolubility of micronutrients in the soil [16]. For countries like Ethiopia, where there is no micronutrient application in the form of chemical fertilizers or organic elements, micronutrients are removed through crop harvest [17]. However, there is very little information available in Ethiopia about micronutrient levels in soils. The study carried out on the micronutrient status of Ethiopian soils reported that the contents of Fe and Mn were usually at an adequate level, while molybdenum (Mo) and $\mathrm{Zn}$ contents were variable [18]. Research finding showed that the micronutrient content of the soil is influenced by several factors among which soil organic matter content, soil reaction, and clay content are the major one [19]. The status of micronutrients on Andisols of Rift Valley using different analytical methods was studied [20].

However, information related to the use of universal extractants such as, 0.026 M EDTA, $0.01 \mathrm{M} \mathrm{CaCl}_{2}, 0.01 \mathrm{M} \mathrm{BaCl}_{2}, 0.1 \mathrm{M} \mathrm{BaCl}_{2}, 0.02 \mathrm{M} \mathrm{SrCl}_{2}$, Mehlich 3 and AB-DTPA for determination of micronutrients $(\mathrm{Fe}, \mathrm{Cu}, \mathrm{Mn}$ and $\mathrm{Zn})$ in Ethiopian soil is scarce. The purpose of this work was, therefore, to assess the effectiveness of these universal extractants for soils of selected $\mathrm{pH}$ and to identify the most suitable universal extractant for the studied soils. This study has also focused on relationships between the conventional soil testing methodologies for selected micronutrients and the universal extractants proposed.

\section{EXPERIMENTAL}

\section{Description of the study areas}

The study was conducted in some selected parts of Ethiopia. Viz., Eastern Harargie Zone (Babile and Haramaya Districts), Wolaita Zone (Boloso Bombe, Damot Pulasa, Damot Sore and Humbo Districts) and Dire Dawa Administrative Council as shown in Figure 1. 

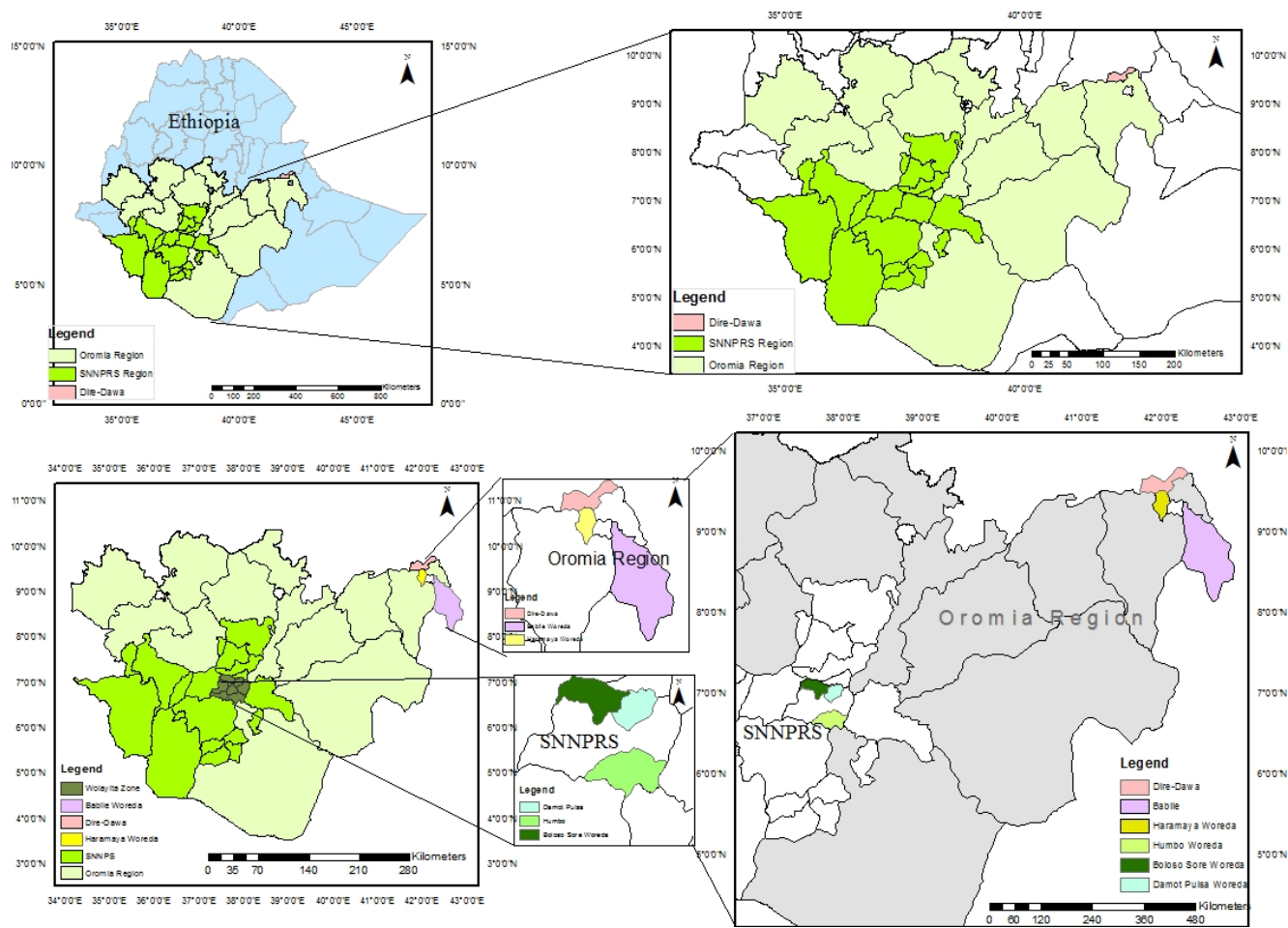

Figure 1. Location map of the study areas

Babile District lies between $8^{0} 09^{\prime}$ and $9^{0} 23^{\prime} \mathrm{N}$ latitude, and between $42^{0} 15^{\prime}$ and $42^{0} 53^{\prime} \mathrm{E}$ longitude and an altitude between 1239 and 1441 meters above sea level (masl). The rainy season of the area is bimodal; the short rainy season extends from March to May and the main rainy season stretches from July to September. The annual rainfall varies from 450 to $900 \mathrm{~mm}$ and the annual mean maximum and minimum temperatures are 30.9 and $13.5{ }^{\circ} \mathrm{C}$, respectively [21]. Considering the land use, the land was continuously cultivated for sorghum, maize and ground nut which are the dominant crops for this District. Similarly, Haramaya District is located on the Eastern escarpment of the Rift Valley near $09^{\circ} 26^{\prime} \mathrm{N}$ and $41^{0} 55^{\prime}$ to $42^{\circ} 03^{\prime} \mathrm{E}$, at an altitude of 1970 to 1980 masl. Some of the dominant crops in this District are sorghum, maize, wheat and common beans. The total annual average rainfall is $827 \mathrm{~mm}$ and the mean temperature is $16.8{ }^{0} \mathrm{C}$.

Wolaita Zone is roughly located between $6.4^{0}-7.1^{0} \mathrm{~N}$ and $37.4^{0}-38.2^{0} \mathrm{E}$, latitude and longitude, respectively. The rainfall in the zone is characterized by bimodal distribution pattern and the main rainy season (Maher) is between June and continues up to end of September and Belg is from late February to late March/early April. The annual average temperature of the zone is $21.86{ }^{\circ} \mathrm{C}$. The altitude of the zone ranges from 501 to 3000 masl [22]. Considering the land use, the land was intensively cultivated for the major crops including maize, barley, sweet potato and teff. On the other hand, urea and diammonium phosphate (DAP) were commonly used as a fertilizer by the farmers in this Zone.

The Dire Dawa Administrative Council (DDAC) is geographically located in the eastern part of the country specifically lying at latitude and longitude of $9^{0} 36^{\prime} \mathrm{N}$ and $41^{0} 52^{\prime} \mathrm{E}$, 
respectively. The DDAC comprises of diversified topographic features, its altitude ranging from 960 in the northeast to 2450 masl in the southwest. The cereal crops grown in the DDAC are sorghum and maize only. Besides the cereal crops, a variety of vegetables such as onion, tomato, pepper and cabbages, cash crops such as khat, coffee and fruit crops like papaya, banana and guava are also grown [23].

\section{Site selection}

The study was conducted by collecting 7 representative soil samples within the $\mathrm{pH}$ range of 4.55.0, 5.1-5.5, 5.6-6.0, 6.1-6.5, 6.6-7.3, 7.4-7.8, and 7.9-8.4. The sites were selected by purposive sampling in order to get soils having different $\mathrm{pH}$ values.

\section{Sample collection and preparation}

Composite surface soil samples $(0-20 \mathrm{~cm}$ depth $)$ were collected from the studied areas. The samples were bagged, labeled and transported to the laboratory for preparation and analysis of selected soil properties following standard laboratory procedures.

\section{Instrumentation}

A stainless steel soil sampling auger was used to collect all the soil samples from sampling sites. All the soil samples were weighed on a digital analytical balance (Mettler Toledo, Switzerland) with \pm 0.0001 g precision. $\mathrm{pH}$ meter (Belgium, C835) was used during $\mathrm{pH}$ measurement of the soil. The concentrations of $\mathrm{Fe}, \mathrm{Cu}, \mathrm{Mn}$ and $\mathrm{Zn}$ in the soil samples were determined by Flame Atomic Absorption Spectrophotometer (FAAS) (Buck Scientific Model 210 VGP AAS, East Norwalk, USA) by using hallow cathode lamps with air acetylene flame. A Bruker AXS Diffractometer, Model D-78187 Karlsruhe, Germany, was used for X-ray diffraction (XRD) analysis of soil samples. The concentrations of $\mathrm{SiO}_{2}, \mathrm{Al}_{2} \mathrm{O}_{3}, \mathrm{Fe}_{2} \mathrm{O}_{3}, \mathrm{CaO}, \mathrm{MgO}, \mathrm{Na}_{2} \mathrm{O}, \mathrm{K}_{2} \mathrm{O}$, $\mathrm{MnO}, \mathrm{P}_{2} \mathrm{O}_{5}, \mathrm{TiO}_{2}$ and $\mathrm{H}_{2} \mathrm{O}$ in the soil samples were determined by Varian Spectra Atomic Absorption Spectrometer (Shimadzu, USA).

\section{Reagents and chemicals}

Chemicals and reagents used in this study were all of analytical grades. Some of the chemicals and reagents used in this study were; $\mathrm{SrCl}_{2}(98 \%$, AnalaR, $\mathrm{BDH}), \mathrm{CaCl}_{2} .2 \mathrm{H}_{2} \mathrm{O}$ (AnalaR, BDH, England), $\mathrm{BaCl}_{2} \cdot 2 \mathrm{H}_{2} \mathrm{O}$ (AnalaR, BDH, England), $\mathrm{NH}_{4} \mathrm{HCO}_{3}$ (98.5\%, BDH, India), DTPA (99\%, $\mathrm{BDH}$, India), $\mathrm{NH}_{4} \mathrm{~F}$ (AnalaR, BHD, England), EDTA (99.5\%, AnalaR, BDH, England), $\mathrm{NH}_{4} \mathrm{NO}_{3}$ (AnalaR, BDH, England), concentrated $\mathrm{CH}_{3} \mathrm{COOH}$ (AnalaR, BDH) and concentrated $\mathrm{HNO}_{3}(69 \%$, AnalaR, UK) were used as extractant for the determination of $\mathrm{Fe}, \mathrm{Cu}, \mathrm{Mn}$ and $\mathrm{Zn}$ in soil samples. Stock standard solutions having concentration of $1000 \mathrm{mg} \mathrm{L}^{-1}$ were used for the preparation of serially diluted working solutions for each nutrient for calibration. Deionized water was used for sample preparation, dilution and rinsing the apparatus prior to sampling.

\section{Physicochemical analysis}

Oxide content of the soil samples were determined by using Lithium Metaborate + Lithium Tetraborate $\left(\mathrm{LiBO}_{2}+\mathrm{LiB}_{4} \mathrm{O}_{7}\right)$ fusion method [24]. Soil samples for XRD analyses were ground in to powder form using a mortar and pestle. The powdered samples obtained were loaded in sample holders and mounted in the Bruker AXS Diffractometer system for identification of minerals [25]. Both oxide content and XRD analyses were carried out in Geological Survey of Ethiopia, Addis Ababa. Soil $\mathrm{pH}$ was measured potentiometrically in $\mathrm{H}_{2} \mathrm{O}$ at the ratio of 1:2.5 for 
Evaluation of universal extractants for determination of Selected micronutrients from soil 203

soil: $\mathrm{H}_{2} \mathrm{O}$ using a combined glass electrode $\mathrm{pH}$ meter [26]. For conventional soil testing method, $\mathrm{Fe}, \mathrm{Cu}, \mathrm{Mn}$ and $\mathrm{Zn}$ were determined with DTPA extractant [10]. For universal extractants soil testing method, the collected soil samples were analyzed using $0.026 \mathrm{M}$ EDTA, $0.01 \mathrm{M} \mathrm{CaCl}_{2}$, $0.02 \mathrm{M} \mathrm{SrCl}_{2}, 0.01 \mathrm{M} \mathrm{BaCl}_{2}, 0.1 \mathrm{M} \mathrm{BaCl}_{2}$, Mehlich 3 and AB-DTPA extractants using standard procedure as shown in Table 1.

\section{Experimental design}

Treatments were arranged in a completely randomized design (CRD) format in triplicate. The analysis was carried out at Haramaya University Soil Laboratory using the following extractants: DTPA, 0.026 M EDTA, 0.01 $\mathrm{M} \mathrm{CaCl}_{2}, 0.02 \mathrm{M} \mathrm{SrCl}_{2}, 0.01 \mathrm{M} \mathrm{BaCl}_{2}, 0.1 \mathrm{M} \mathrm{BaCl}_{2}$, Mehlich 3 and AB-DTPA for the determination of $\mathrm{Fe}, \mathrm{Cu}, \mathrm{Mn}$ and $\mathrm{Zn}$ in triplicate.

Table 1. Details of extraction procedure used in the study for conventional and universal extractants soil testing method.

\begin{tabular}{|c|c|c|c|c|}
\hline Methods used & Extractant & Soil : solution & $\begin{array}{c}\text { Shaking } \\
\text { time (min) }\end{array}$ & Reference \\
\hline DTPA & $\begin{array}{l}0.005 \mathrm{M} \text { DTPA }+0.01 \mathrm{M} \\
\mathrm{CaCl}_{2}+0.1 \mathrm{M} \text { TEA }\end{array}$ & $1: 2$ & 120 & {$[10]$} \\
\hline EDTA & $0.026 \mathrm{M}$ EDTA & $1: 10$ & 60 & {$[27]$} \\
\hline Calcium chloride & $0.01 \mathrm{M} \mathrm{CaCl}_{2}$ & $1: 10$ & 30 & {$[28]$} \\
\hline Barium chloride & $0.01 \mathrm{M} \mathrm{BaCl}_{2}$ & $1: 10$ & 30 & [29] \\
\hline Strontium chloride & $0.02 \mathrm{M} \mathrm{SrCl}_{2}$ & $1: 10$ & 30 & {$[30]$} \\
\hline Barium chloride & $0.1 \mathrm{M} \mathrm{BaCl}_{2}$ & $1: 10$ & 30 & [29] \\
\hline Mehlich 3 & $\begin{array}{lcc}0.015 \mathrm{M} \mathrm{NH} & \mathrm{F}+0.25 \mathrm{M} \\
\mathrm{NH}_{4} \mathrm{NO}_{3}+0.2 & \mathrm{M} \\
\mathrm{CH}_{3} \mathrm{COOH}+0.013 & \mathrm{M} \\
\mathrm{HNO}_{3}+0.001 \mathrm{M} \text { EDTA } & \\
\end{array}$ & $1: 10$ & 5 & [11] \\
\hline AB-DTPA & $\begin{array}{l}1 \mathrm{M} \mathrm{NH} \mathrm{HCO}_{3}+0.005 \mathrm{M} \\
\text { DTPA }(\mathrm{pH} \mathrm{7.6)}\end{array}$ & $1: 2$ & 15 & {$[31]$} \\
\hline
\end{tabular}

DTPA = diethylene triamine penta acetic acid; EDTA $=$ ethylene diamine tetra acetic acid; AB-DTPA = ammonium bicarbonate-diethylene triamine penta acetic acid.

\section{Recovery test}

Recovery test is one of the most commonly used techniques for validation of analytical results. It is the technique used for evaluating how far the analytical method is acceptable for its intended purpose. Because of the absence of certified reference material for the soil samples in the laboratory, where the analysis was carried out, validity of the methods employed for the investigation was assured by spiking the samples with standard solution of known concentration of the analyte nutrients to be analyzed [32]. To this effect, appropriate volumes of stock solutions of $\mathrm{Fe}, \mathrm{Cu}, \mathrm{Mn}$ and $\mathrm{Zn}$ were spiked at once into a soil sample using volumetric flask and analyzed for their respective spiked metals using atomic absorption spectroscopy [33]. Spike recovery is usually required to at least $70 \%$ [34]. The percentage recovery of the sample was calculated.

\section{Method detection limit (MDL)}

Seven replicate blank samples were analyzed following the same procedures that have been utilized for the soil samples. Each of the blank samples was analyzed for their nutrient contents, such as $\mathrm{Fe}, \mathrm{Cu}, \mathrm{Mn}$ and $\mathrm{Zn}$ by atomic absorption spectroscopy. Then, the standard deviations of seven blanks were calculated. The standard deviations were multiplied by three to give MDL [33]. 
Data analysis

Analysis of variance (ANOVA) was used to test differences between two or more means. The general linear model (GLM) procedure of Statistical Analysis System version 9.13 [35] was used as a tool for statistical analysis and to test significance differences between treatment means. The least significance difference (LSD) test was employed for the mean separation of different methods that were found to be significantly different in statistical terms at $p=0.05$. The correlations coefficients between methods were also determined by using the same software.

\section{RESULTS AND DISCUSSION}

\section{Physicochemical properties}

The X-ray powder diffraction data showed that all the studied areas contain quartz minerals which ranged from 7.5 to $44.9 \%$ with hexagonal structure (Table 2) and the value was higher for soil collected from Dire Dawa and lower for soil collected from Babile.

The dominant clay minerals in acid and neutral soils in the studied areas (Damot Sore, Boloso Bombe, Damot Pulasa, Humbo and Haramaya Districts) were albite which constitutes $49.3 \%$ albite low in Damot Sore, $34.5 \%$ albite high in Boloso Bonibe, $77.1 \%$ albite low in Damot Pulasa, $71.7 \%$ albite calcian low in Humbo and $49.7 \%$ albite low in Haramaya. This could be due to an appreciable amount of $\mathrm{Al}_{2} \mathrm{O}_{3}$ and $\mathrm{Fe}_{2} \mathrm{O}_{3}$ in acidic and neutral soil. On the other hand, in alkaline soils (Babile District and Dire Dawa Administrative Council), the dominant clay minerals were microcline and feldspar potassian which constitutes $43.6 \%$ of microcline in Babile and 45.7\% feldspar potassian in Dire Dawa Administrative Council. This could possibly be explained by substantial amount of $\mathrm{K}_{2} \mathrm{O}(4.58 \%)$ in Babile District.

Acidic soils (Damot Sore, Boloso Bombe and Humbo Districts) and neutral soil (Haramaya District) contain high amount of titanium oxide $\left(\mathrm{TiO}_{2}\right)$ than alkaline soils (Babile District and Dire Dawa Administrative Council).

The $\mathrm{pH}\left(\mathrm{H}_{2} \mathrm{O}\right)$ values of soils varied from 4.75 to 8.22 (Table 3). According to Donald [36], the $\mathrm{pH}$ ranges of the soils in the studied areas are from very strongly acidic to moderately alkaline. The lowest (4.75) value was observed in Damot Sore, whereas the highest (8.22) was found in Dire Dawa. The higher acidity of the soils of Damot Sore and Boloso Bombe Districts are mainly due to the high rainfall in the area which results in leaching of exchangeable cations.

The amounts of basic oxides such as calcium oxide $(\mathrm{CaO})$, magnesium oxide $(\mathrm{MgO})$, potassium oxide $\left(\mathrm{K}_{2} \mathrm{O}\right)$ and sodium oxide $\left(\mathrm{Na}_{2} \mathrm{O}\right)$ were higher in alkaline and neutral soils than acidic soils except the amount of $\mathrm{Na}_{2} \mathrm{O}$ which was higher in acidic soils particularly Damot Pulasa and Humbo Districts (Table 3). An appreciable amount of $\mathrm{Na}_{2} \mathrm{O}$ was observed in Damot Pulasa and Humbo Districts. This is likely to be attributed to the clay mineralogy of the soil which contain large amount of albite calcian low (71.7\%) for Humbo District and Albite low (77.1\%) for Damot Pulassa District (Table 2).

The experimental soil, particularly the acidic soils contain an appreciable amount of aluminum oxide $\left(\mathrm{Al}_{2} \mathrm{O}_{3}\right)$, iron (III) oxide $\left(\mathrm{Fe}_{2} \mathrm{O}_{3}\right)$ and manganese (II) oxide (MnO) (Table 3). The $\mathrm{Al}_{2} \mathrm{O}_{3}, \mathrm{Fe}_{2} \mathrm{O}_{3}$ and $\mathrm{MnO}$ content of the soil ranged from 6.87 to $16.80 \%, 3.98$ to $10.4 \%$ and 0.06 to $0.26 \%$, respectively.

\section{Analytical method of detection limit}

The calculated limits of detection for the soil samples were given in Table 4. The method detection limits were generally comparable with that of instrument detection limit. Moreover, the method detection limits for all the nutrients analyzed were low enough $\left(\leq 0.06 \mathrm{mg} \mathrm{kg}^{-1}\right)$ to determine the nutrients in the soil samples. This implies that the methods were applicable for the determination of selected micronutrients in the soil. 
Evaluation of universal extractants for determination of Selected micronutrients from soil 205

Table 2. The XRD analysis of soils of the study areas.

\begin{tabular}{|c|c|c|c|}
\hline Sampling site & Mineral identified & Composition (\%) & Structure \\
\hline \multirow[t]{4}{*}{ Damot Sore } & Goethite & 11.3 & Orthorhombic \\
\hline & Albite low & 49.3 & Triclinic \\
\hline & Quartz alpha & 9.60 & Hexagonal \\
\hline & Kaolinite & 29.8 & Monoclinic \\
\hline \multirow[t]{4}{*}{ Boloso Bombe } & Quartz & 34.5 & Hexagonal \\
\hline & Pyrophyllite & 15.4 & Triclinic \\
\hline & Phosphosiderite & 15.7 & Monoclinic \\
\hline & Albite high & 34.5 & Triclinic \\
\hline \multirow[t]{3}{*}{ Damot Pulasa } & Quartz alpha & 15.1 & Hexagonal \\
\hline & Albite low & 77.1 & Triclinic \\
\hline & Kaolinite & 7.80 & Triclinic \\
\hline \multirow[t]{3}{*}{ Humbo } & Albite calcian low & 71.7 & Triclinic \\
\hline & Quartz alpha & 12.7 & Hexagonal \\
\hline & Goethite & 15.6 & Orthorhombic \\
\hline \multirow[t]{4}{*}{ Haramaya } & Quartz alpha & 9.70 & Hexagonal \\
\hline & Dickite & 28.7 & Monoclinic \\
\hline & Albite low & 49.7 & Triclinic \\
\hline & Goethite & 11.8 & Orthorhombic \\
\hline \multirow[t]{4}{*}{ Babile } & Goethite & 9.55 & Orthorhombic \\
\hline & Albite & 39.5 & Triclinic \\
\hline & Microcline & 43.6 & Triclinic \\
\hline & Quartz alpha & 7.50 & Hexagonal \\
\hline \multirow[t]{3}{*}{ Dire Dawa } & Calcite, magnesian & 9.40 & Rhombohedral \\
\hline & Quartz & 44.9 & Hexagonal \\
\hline & Feldspar potassian & 45.7 & Triclinic \\
\hline
\end{tabular}

Table 3. Oxide content and soil reaction of soils of the study areas.

\begin{tabular}{|c|c|c|c|c|c|c|c|}
\hline \multirow{2}{*}{ Oxides (\%) } & \multicolumn{7}{|c|}{ Sampling site } \\
\cline { 2 - 8 } & Damot Sore & Boloso Bombe & Damot Pulasa & Humbo & Haramaya & Babile & Dire Dawa \\
\hline $\mathrm{SiO}_{2}$ & 51.4 & 50.5 & 70.3 & 62.1 & 54.6 & 67.9 & 26.8 \\
\hline $\mathrm{Al}_{2} \mathrm{O}_{3}$ & 16.8 & 16.6 & 8.44 & 11.2 & 15.2 & 13.3 & 6.87 \\
\hline $\mathrm{Fe}_{2} \mathrm{O}_{3}$ & 9.30 & 10.4 & 4.55 & 8.70 & 6.90 & 4.88 & 3.98 \\
\hline $\mathrm{CaO}$ & 0.06 & 0.30 & 0.52 & 1.16 & 3.02 & 1.96 & 29.5 \\
\hline $\mathrm{MgO}$ & 0.30 & 0.32 & 0.26 & 0.84 & 1.96 & 0.88 & 2.20 \\
\hline $\mathrm{Na}_{2} \mathrm{O}$ & 1.02 & 1.14 & 2.70 & 2.04 & 1.22 & 1.68 & 0.92 \\
\hline $\mathrm{K}_{2} \mathrm{O}$ & 1.82 & 1.88 & 2.92 & 2.38 & 2.54 & 4.58 & 1.28 \\
\hline $\mathrm{MnO}$ & 0.18 & 0.24 & 0.18 & 0.26 & 0.12 & 0.06 & 0.14 \\
\hline $\mathrm{P}_{2} \mathrm{O}_{5}$ & 0.08 & 0.10 & 0.07 & 0.30 & 0.12 & 0.06 & 0.20 \\
\hline $\mathrm{TiO}_{2}$ & 1.15 & 1.34 & 0.49 & 1.66 & 1.23 & 0.65 & 0.65 \\
\hline $\mathrm{H}_{2} \mathrm{O}$ & 5.40 & 4.95 & 1.84 & 2.18 & 5.83 & 1.56 & 3.92 \\
\hline $\mathrm{pH}\left(\mathrm{H}_{2} \mathrm{O}\right)$ & 4.75 & 5.22 & 5.73 & 6.23 & 7.05 & 7.63 & 8.22 \\
\hline
\end{tabular}

\section{Recovery tests}

The percentage recoveries obtained in this study ranged from $90-110 \%, 90-99 \%, 90-110 \%$ and $90-99 \%$ for $\mathrm{Fe}, \mathrm{Cu}, \mathrm{Mn}$ and $\mathrm{Zn}$, respectively, except for $0.01 \mathrm{M} \mathrm{CaCl}_{2}, 0.01 \mathrm{M} \mathrm{BaCl}_{2}$ and $0.1 \mathrm{M}$ $\mathrm{BaCl}_{2}$ for $\mathrm{Fe}$. The results for the recovery test were found to be all in the acceptable range validating the reliability of the tested extractants (Tables 5 and 6). The results were in agreement with previous findings [33, 37, 38]. 
Table 4. Method detection limit for the soil samples and extractants.

\begin{tabular}{|l|c|c|c|c|c|c|c|c|}
\hline \multirow{2}{*}{ Methods used } & \multicolumn{3}{|c|}{ Instrument detection limit $\left(\mathrm{mg} \mathrm{kg}^{-1}\right)$} & \multicolumn{3}{c|}{ Method detection limit $\left(\mathrm{mg} \mathrm{kg}^{-1}\right)$} \\
\cline { 2 - 10 } & $\mathrm{Fe}$ & $\mathrm{Cu}$ & $\mathrm{Mn}$ & $\mathrm{Zn}$ & $\mathrm{Fe}$ & $\mathrm{Cu}$ & $\mathrm{Mn}$ & $\mathrm{Zn}$ \\
\hline DTPA & 0.03 & 0.02 & 0.001 & 0.005 & 0.05 & 0.03 & 0.02 & 0.03 \\
\hline EDTA & 0.03 & 0.02 & 0.001 & 0.005 & 0.03 & 0.03 & 0.02 & 0.01 \\
\hline $0.01 \mathrm{M} \mathrm{CaCl}_{2}$ & 0.03 & 0.02 & 0.001 & 0.005 & 0.06 & 0.03 & 0.03 & 0.03 \\
\hline $0.01 \mathrm{M} \mathrm{BaCl}_{2}$ & 0.03 & 0.02 & 0.001 & 0.005 & 0.05 & 0.02 & 0.02 & 0.02 \\
\hline $0.02 \mathrm{M} \mathrm{SrCl}_{2}$ & 0.03 & 0.02 & 0.001 & 0.005 & 0.04 & 0.02 & 0.06 & 0.02 \\
\hline $0.1 \mathrm{M} \mathrm{BaCl}_{2}$ & 0.03 & 0.02 & 0.001 & 0.005 & 0.05 & 0.03 & 0.02 & 0.02 \\
\hline Mehlich 3 & 0.03 & 0.02 & 0.001 & 0.005 & 0.03 & 0.04 & 0.05 & 0.04 \\
\hline AB-DTPA & 0.03 & 0.02 & 0.001 & 0.005 & 0.03 & 0.06 & 0.05 & 0.06 \\
\hline
\end{tabular}

DTPA = diethylene triamine penta acetic acid; EDTA = ethylene diamine tetra acetic acid; AB-DTPA = ammonium bicarbonate-diethylene triamine penta acetic acid.

Table 5. Recovery test results for the soil samples and the methods for $\mathrm{Fe}$ and $\mathrm{Cu}$ analysis.

\begin{tabular}{|l|c|c|c|c|c|c|}
\hline $\begin{array}{l}\text { Extractants } \\
(\text { methods }) \text { used }\end{array}$ & $\begin{array}{c}\text { Nutrient } \\
\text { extracted }\end{array}$ & $\begin{array}{c}\text { Concentration } \\
\text { in the sample } \\
\left(\mathrm{mg} \mathrm{kg}^{-1}\right)^{\mathrm{a}}\end{array}$ & $\begin{array}{c}\text { Amount } \\
\text { added }(\mathrm{mg} \\
\left.\mathrm{kg}^{-1}\right)\end{array}$ & $\begin{array}{c}\text { Concentration in } \\
\text { the spiked sample } \\
\left(\mathrm{mg} \mathrm{kg}^{-1}\right)^{\mathrm{a}}\end{array}$ & $\begin{array}{c}\text { Amount } \\
\text { recovered } \\
\left(\mathrm{mg} \mathrm{kg}^{-1}\right)\end{array}$ & $\begin{array}{c}\text { Recovery } \\
(\%)\end{array}$ \\
\hline DTPA & $\mathrm{Fe}$ & $18.3 \pm 0.1$ & 5.00 & $23.0 \pm 0.2$ & 4.70 & $94 \pm 0.9$ \\
\hline EDTA & $\mathrm{Fe}$ & $173 \pm 0.2$ & 10.0 & $184 \pm 0.1$ & 11.0 & $110 \pm 0.7$ \\
\hline $0.01 \mathrm{M} \mathrm{CaCl}_{2}$ & $\mathrm{Fe}$ & $0.20 \pm 0.1$ & 0.05 & $0.23 \pm 0.1$ & 0.03 & $60 \pm 0.4$ \\
\hline $0.01 \mathrm{M} \mathrm{BaCl}_{2}$ & $\mathrm{Fe}$ & $0.82 \pm 0.2$ & 0.10 & $0.89 \pm 0.1$ & 0.07 & $70 \pm 0.2$ \\
\hline $0.02 \mathrm{M} \mathrm{SrCl}_{2}$ & $\mathrm{Fe}$ & $11.4 \pm 0.5$ & 1.00 & $12.3 \pm 0.3$ & 0.90 & $90 \pm 0.9$ \\
\hline $\mathrm{Mehlich} \mathrm{3}_{0.1 \mathrm{M} \mathrm{BaCl}}$ & $\mathrm{Fe}$ & $131 \pm 0.5$ & 10.0 & $141 \pm 0.6$ & 10.0 & $100 \pm 0.2$ \\
\hline AB-DTPA & $\mathrm{Fe}$ & $1.21 \pm 0.1$ & 0.10 & $1.29 \pm 0.1$ & 0.08 & $80 \pm 1.3$ \\
\hline DTPA & $\mathrm{Fe}$ & $26.1 \pm 0.1$ & 5.00 & $30.9 \pm 0.3$ & 4.80 & $96 \pm 1.0$ \\
\hline EDTA & $\mathrm{Cu}$ & $2.27 \pm 0.1$ & 0.50 & $2.74 \pm 0.1$ & 0.47 & $94 \pm 0.4$ \\
\hline $0.01 \mathrm{M} \mathrm{CaCl}_{2}$ & $\mathrm{Cu}$ & $2.11 \pm 0.1$ & 0.50 & $2.57 \pm 0.1$ & 0.46 & $92 \pm 0.2$ \\
\hline $0.01 \mathrm{M} \mathrm{BaCl}_{2}$ & $\mathrm{Cu}$ & $8.10 \pm 0.3$ & 1.00 & $9.08 \pm 0.2$ & 0.98 & $98 \pm 0.4$ \\
\hline $0.02 \mathrm{M} \mathrm{SrCl}_{2}$ & $\mathrm{Cu}$ & $9.01 \pm 0.2$ & 1.00 & $10.0 \pm 0.3$ & 0.99 & $99 \pm 0.5$ \\
\hline $\mathrm{Mehlich} 3^{0.1 \mathrm{M} \mathrm{BaCl}}{ }_{2}$ & $\mathrm{Cu}$ & $3.06 \pm 0.4$ & 0.50 & $3.53 \pm 0.1$ & 0.47 & $94 \pm 0.8$ \\
\hline AB-DTPA & $\mathrm{Cu}$ & $3.54 \pm 0.3$ & 0.50 & $4.02 \pm 0.1$ & 0.48 & $96 \pm 0.2$ \\
\hline
\end{tabular}

${ }^{\mathrm{a}}$ Concentration values are average of three analyzed samples \pm standard deviation; ${ }^{\mathrm{b}}$ Recovery values are mean \pm standard deviation.

\section{Universal extractants and their extraction efficiency for some micronutrients}

The concentrations of available $\mathrm{Fe}, \mathrm{Cu}, \mathrm{Mn}$ and $\mathrm{Zn}$ determined in conventional soil testing method were shown in Table 7. The available Fe content of the soil ranged from $2.94 \mathrm{mg} \mathrm{kg} \mathrm{g}^{-1}$ (Dire Dawa site) to $22.6 \mathrm{mg} \mathrm{kg}^{-1}$ (Damot Pulasa District). The concentration of available Fe is generally high in tropical soils; localized deficiencies of Fe are known to occur [39]. In this study, considering $4.5 \mathrm{mg} \mathrm{kg}^{-1}$ DTPA-extractable Fe as the critical value [40], all soil samples in the studied areas are not deficient in available Fe except Dire Dawa Administrative Council. This is in agreement with various works which stated that Fe contents are usually at an adequate level in Ethiopian soils $[18,19]$. The concentration of available $\mathrm{Cu}$ varied from $0.32 \mathrm{mg} \mathrm{kg} \mathrm{kg}^{-1}$ (Boloso Bombe District) to $5.67 \mathrm{mg} \mathrm{kg}^{-1}$ (Haramaya District). The highest available Cu was observed in Haramaya District, whereas the lowest was in Boloso Bombe District. This is due to the strong association of $\mathrm{Cu}$ with soil $\mathrm{OM}$. According to the critical value $\left(0.4-0.6 \mathrm{mg} \mathrm{kg}^{-1}\right)$ of available micronutrients set by Havlin et al. [40] for $\mathrm{Cu}$, the amount of $\mathrm{Cu}$ determined for 
Damot Sore and Babile Districts were in the range of critical limit (marginal range), whereas the amount of $\mathrm{Cu}$ determined for Boloso Bombe District was categorized in low range. This is in agreement with various works which stated that $\mathrm{Cu}$ is most likely deficient in Ethiopian soils [19]. Based on the critical limit of $0.41-0.60 \mathrm{mg} \mathrm{kg}^{-1}[27,40]$, the concentration of $\mathrm{Cu}$ determined in Damot Pulasa, Humbo, Haramaya Districts and Dire Dawa Administrative Council were high. This could possibly be explained by the moderate organic matter content of the soil in these sites.

Table 6. Recovery test results for the soil samples and the methods for Mn and $\mathrm{Zn}$ analysis.

\begin{tabular}{|c|c|c|c|c|c|c|}
\hline \begin{tabular}{|l}
$\begin{array}{l}\text { Extractants } \\
\text { (methods) used }\end{array}$ \\
\end{tabular} & $\begin{array}{l}\text { Nutrient } \\
\text { extracted }\end{array}$ & $\begin{array}{l}\text { Concentration in } \\
\text { the sample } \\
\left(\mathrm{mg} \mathrm{kg}^{-1}\right)^{\mathrm{a}}\end{array}$ & $\begin{array}{l}\text { Amount } \\
\text { added } \\
\left(\mathrm{mg} \mathrm{kg}^{-1}\right)\end{array}$ & $\begin{array}{l}\text { Concentration in } \\
\text { the spiked sample } \\
\left(\mathrm{mg} \mathrm{kg}^{-1}\right)^{\mathrm{a}}\end{array}$ & $\begin{array}{l}\text { Amount } \\
\text { recovered } \\
\left(\mathrm{mg} \mathrm{kg}^{-1}\right)\end{array}$ & $\begin{array}{c}\text { Recovery } \\
(\%)\end{array}$ \\
\hline DTPA & $\mathrm{Mn}$ & $11.8+0.2$ & 1.00 & $12.8+0.1$ & 1.00 & $100+0.5$ \\
\hline EDTA & $\mathrm{Mn}$ & $117+0.6$ & 10.0 & $128+0.3$ & 11.0 & $110+1.2$ \\
\hline $0.01 \mathrm{M} \mathrm{CaCl}_{2}$ & $\mathrm{Mn}$ & $5.51+0.3$ & 1.00 & $6.42+0.1$ & 0.91 & $95+0.4$ \\
\hline $0.01 \mathrm{M} \mathrm{BaCl}_{2}$ & $\mathrm{Mn}$ & $9.60 \pm 0.1$ & 1.00 & $10.5 \pm 0.3$ & 0.90 & $90 \pm 0.8$ \\
\hline $0.02 \mathrm{M} \mathrm{SrCl}_{2}$ & $\mathrm{Mn}$ & $5.34 \pm 0.2$ & 1.00 & $6.25 \pm 0.1$ & 0.91 & $91 \pm 0.3$ \\
\hline Mehlich 3 & $\mathrm{Mn}$ & $92.6 \pm 0.4$ & 10.0 & $103+0.2$ & 10.4 & $104+0.8$ \\
\hline $0.1 \mathrm{M} \mathrm{BaCl}_{2}$ & $\mathrm{Mn}$ & $8.86 \pm 0.1$ & 1.00 & $9.78 \pm 0.1$ & 0.92 & $92 \pm 0.7$ \\
\hline AB-DTPA & $\mathrm{Mn}$ & $36.2 \pm 0.2$ & 5.00 & $41.1 \pm 0.4$ & 4.90 & $98 \pm 1.3$ \\
\hline DTPA & $\mathrm{Zn}$ & $5.97 \pm 0.1$ & 1.00 & $6.95+0.1$ & 0.98 & $98+0.2$ \\
\hline EDTA & $\mathrm{Zn}$ & $6.30 \pm 0.2$ & 1.00 & $7.29 \pm 0.2$ & 0.99 & $99 \pm 0.3$ \\
\hline $0.01 \mathrm{M} \mathrm{CaCl}_{2}$ & $\mathrm{Zn}$ & $0.51 \pm 0.1$ & 0.10 & $0.60 \pm 0.1$ & 0.09 & $90+0.5$ \\
\hline $0.01 \mathrm{M} \mathrm{BaCl}_{2}$ & $\mathrm{Zn}$ & $1.52 \pm 0.1$ & 0.50 & $1.98 \pm 0.1$ & 0.46 & $92 \pm 0.8$ \\
\hline $0.02 \mathrm{M} \mathrm{SrCl}_{2}$ & $\mathrm{Zn}$ & $1.09 \pm 0.3$ & 0.10 & $1.18 \pm 0.1$ & 0.09 & $90 \pm 0.2$ \\
\hline Mehlich 3 & $\mathrm{Zn}$ & $2.20 \pm 0.1$ & 1.00 & $3.14 \pm 0.2$ & 0.98 & $94 \pm 0.3$ \\
\hline $0.1 \mathrm{M} \mathrm{BaCl}_{2}$ & $\mathrm{Zn}$ & $1.93+0.2$ & 0.50 & $2.39 \pm 0.1$ & 0.46 & $92+0.2$ \\
\hline AB-DTPA & $\mathrm{Zn}$ & $2.33+0.03$ & 0.50 & $2.80+0.2$ & 0.47 & $94+0.8$ \\
\hline
\end{tabular}

${ }^{\mathrm{a}}$ Concentration values are average of three analyzed samples \pm standard deviation; ${ }^{\mathrm{b}}$ Recovery values are mean \pm standard deviation.

Table 7. Available micronutrients in the soil samples of the study areas using diethylene triamine pentaacetic acid (DTPA) extractant.

\begin{tabular}{|l|c|c|c|c|}
\hline Sampling site & $\mathrm{Fe}\left(\mathrm{mg} \mathrm{kg}^{-1}\right)$ & $\mathrm{Cu}\left(\mathrm{mg} \mathrm{kg}^{-1}\right)$ & $\mathrm{Mn}\left(\mathrm{mg} \mathrm{kg}^{-1}\right)$ & $\mathrm{Zn}\left(\mathrm{mg} \mathrm{kg}^{-1}\right)$ \\
\hline Damot Sore & $18.3 \pm 0.02$ & $0.41 \pm 0.02$ & $17.4 \pm 0.01$ & $11.7 \pm 0.11$ \\
\hline Boloso Bombe & $18.2 \pm 0.02$ & $0.32 \pm 0.01$ & $22.3 \pm 0.05$ & $17.4 \pm 0.10$ \\
\hline Damot Pulasa & $22.6 \pm 0.14$ & $1.09 \pm 0.05$ & $12.9 \pm 0.02$ & $11.6 \pm 0.35$ \\
\hline Humbo & $18.5 \pm 0.08$ & $0.93 \pm 0.01$ & $14.4 \pm 0.05$ & $13.3 \pm 0.15$ \\
\hline Haramaya & $6.81 \pm 0.06$ & $5.67 \pm 0.06$ & $11.8 \pm 0.07$ & $2.65 \pm 0.04$ \\
\hline Babile & $4.67 \pm 0.03$ & $0.60 \pm 0.01$ & $5.47 \pm 0.05$ & $1.81 \pm 0.02$ \\
\hline Dire Dawa & $2.94 \pm 0.01$ & $2.12 \pm 0.07$ & $3.43 \pm 0.01$ & $2.01 \pm 0.03$ \\
\hline
\end{tabular}

The concentration of available $\mathrm{Mn}$ in the studied soil samples varied from $3.43 \mathrm{mg} \mathrm{kg}^{-1}$ in Dire Dawa Administrative Council to $22.3 \mathrm{mg} \mathrm{kg}^{-1}$ in Boloso Bombe District. According to critical value $\left(<1 \mathrm{mg} \mathrm{kg}^{-1}\right)$ of available micronutrients set by Havlin et al. [40] for $\mathrm{Mn}$, the amounts of Mn determined in the soil samples for the studied areas may not be deficient for crop production. This is in agreement to various research works who reported that the contents of Mn were usually at an adequate level $[18,19]$.

The concentration of available $\mathrm{Zn}$ in the studied soil samples varied from $1.81 \mathrm{mg} \mathrm{kg}^{-1}$ to $17.4 \mathrm{mg} \mathrm{kg}^{-1}$. The lowest amount of available $\mathrm{Zn}$ was found in Babile District. This is due to organic matter degradation, which is aggravated by the continuous and intensive cultivation in 
this site. The highest amount of available $\mathrm{Zn}$ was found in Boloso Bombe District. According to critical value $\left(0.6-1 \mathrm{mg} \mathrm{kg}^{-1}\right)$ of available micronutrients set by Havlin et al. [40] for $\mathrm{Zn}$, the amount of available $\mathrm{Zn}$ determined in all the studied areas may not be deficient for crop production. Generally availability of $\mathrm{Zn}$ decreases with increasing $\mathrm{pH}$. This is due to increased adsorptive capacity, formation of hydrolyzed forms of $\mathrm{Zn}$, possible chemisorptions on calcium carbonate and co-precipitation in iron oxides.

The relationships among $\mathrm{Fe}, \mathrm{Cu}, \mathrm{Mn}$ and $\mathrm{Zn}$ determined by universal extractants were tested for statistical significance as shown in Table 8. The DTPA method, which is the standard method for determination of available $\mathrm{Fe}, \mathrm{Cu}, \mathrm{Mn}$ and $\mathrm{Zn}$ shows significant correlation with EDTA, $0.01 \mathrm{M} \mathrm{CaCl}_{2}, 0.01 \mathrm{M} \mathrm{BaCl}_{2}, 0.02 \mathrm{M} \mathrm{SrCl}_{2}$, Mehlich 3, $0.1 \mathrm{M} \mathrm{BaCl}_{2}$ and AB-DTPA extractants. However, the highest correlation coefficients $(r=0.95),(r=0.99)$ and $(r=0.97)$ were found between DTPA and AB-DTPA at $(\mathrm{p}<0.001)$ for the determination of $\mathrm{Fe}, \mathrm{Cu}$ and $\mathrm{Zn}$, respectively. Similarly, for the determination of $\mathrm{Mn}$, high correlation coefficients were observed between DTPA and universal extractants $\left(0.01 \mathrm{M} \mathrm{CaCl}_{2}, 0.01 \mathrm{M} \mathrm{BaCl}_{2}, 0.02 \mathrm{M} \mathrm{SrCl}_{2}\right.$, $0.1 \mathrm{M} \mathrm{BaCl}_{2}$ and AB-DTPA) at $(\mathrm{p}<0.01)$.

Table 8. Correlation values among the different extractants for the determination of $\mathrm{Fe}, \mathrm{Cu}, \mathrm{Mn}$ and $\mathrm{Zn}$ in soils of the studied areas.

\begin{tabular}{|c|c|c|c|c|c|c|c|c|}
\hline $\begin{array}{c}\text { Element/ } \\
\text { nutrient }\end{array}$ & $\begin{array}{c}\text { Method/ } \\
\text { extractant used }\end{array}$ & $\begin{array}{c}0.026 \mathrm{M} \\
\text { EDTA }\end{array}$ & $\begin{array}{c}0.01 \mathrm{M} \\
\mathrm{CaCl}_{2}\end{array}$ & $\begin{array}{c}0.01 \mathrm{M} \\
\mathrm{BaCl}_{2}\end{array}$ & $\begin{array}{c}0.02 \mathrm{M} \\
\mathrm{SrCl}_{2}\end{array}$ & $\begin{array}{c}\text { Mehlich } \\
3\end{array}$ & $\begin{array}{c}0.1 \mathrm{M} \\
\mathrm{BaCl}_{2}\end{array}$ & $\begin{array}{c}\mathrm{AB}- \\
\mathrm{DTPA}\end{array}$ \\
\hline $\mathrm{Fe}$ & DTPA & $0.79^{* *}$ & $0.51^{\mathrm{ns}}$ & $0.48^{\mathrm{ns}}$ & $0.79^{* *}$ & $0.75^{* *}$ & $0.69^{\mathrm{ns}}$ & $0.95^{* * *}$ \\
\hline & AB-DTPA & $0.90^{* * *}$ & - & - & $0.82^{* * *}$ & $0.88^{* * *}$ & - & 1.00 \\
\hline $\mathrm{Cu}$ & DTPA & $0.95^{* * *}$ & $0.95^{* * *}$ & $0.53^{\mathrm{ns}}$ & $0.81^{*}$ & $0.98^{* * *}$ & $0.12^{\text {ns }}$ & $0.99^{* * *}$ \\
\hline & AB-DTPA & $0.94^{* *}$ & $0.92^{* *}$ & - & $0.77^{*}$ & $0.99^{* * *}$ & - & 1.00 \\
\hline $\mathrm{Mn}$ & DTPA & $0.77^{* *}$ & $0.90^{* *}$ & $0.87^{* *}$ & $0.86^{* *}$ & $0.75^{* *}$ & $0.89^{* *}$ & $0.85^{* *}$ \\
\hline & $0.01 \mathrm{M} \mathrm{CaCl}{ }_{2}$ & - & 1.00 & $0.88^{* *}$ & $0.89^{* *}$ & - & $0.94^{* *}$ & - \\
\hline $\mathrm{Zn}$ & DTPA & $0.84^{* *}$ & $0.92^{* *}$ & $0.84^{* *}$ & $0.78^{*}$ & $0.78^{* *}$ & $0.77^{*}$ & $0.97^{* * *}$ \\
\hline & AB-DTPA & $0.92^{* *}$ & $0.97^{* * *}$ & - & - & $0.79^{*}$ & - & 1.00 \\
\hline
\end{tabular}

$*, * *, * * *$ Significant at $\mathrm{p} \leq 0.05,0.01$, and $0.001 ; \mathrm{ns}=$ non-significant.

The available Fe vary from $0.2 \mathrm{mg} \mathrm{kg}^{-1}$ to $173 \mathrm{mg} \mathrm{kg}^{-1}$ (Damot Sore District), from $0.23 \mathrm{mg}$ $\mathrm{kg}^{-1}$ to $176 \mathrm{mg} \mathrm{kg}^{-1}$ (at Boloso Bombe District), from $0.3 \mathrm{mg} \mathrm{kg}^{-1}$ to $191 \mathrm{mg} \mathrm{kg}^{-1}$ (Damot Pulasa District), from $0.33 \mathrm{mg} \mathrm{kg}^{-1}$ to $181 \mathrm{mg} \mathrm{kg}^{-1}$ (Humbo District), from $0.27 \mathrm{mg} \mathrm{kg}^{-1}$ to $177 \mathrm{mg} \mathrm{kg}^{-1}$ (Haramaya District), from $0.25 \mathrm{mg} \mathrm{kg}^{-1}$ to $86.4 \mathrm{mg} \mathrm{kg}^{-1}$ (Babile District) and from $0.16 \mathrm{mg} \mathrm{kg}^{-1}$ to $16.4 \mathrm{mg} \mathrm{kg}^{-1}$ (Dire Dawa Administrative Council) as shown in Table 9. The order of extraction efficiency of the tested universal extractants for acidic and neutral soils was: EDTA $>$ Mehlich $3>$ AB-DTPA $>0.02 \mathrm{M} \mathrm{SrCl}_{2}>0.1 \mathrm{M} \mathrm{BaCl}_{2}>0.01 \mathrm{M} \mathrm{BaCl}_{2}>0.01 \mathrm{M} \mathrm{CaCl}_{2}$. However, the percentage recovery results for $\mathrm{Fe}$ (Table 5) showed that $0.1 \mathrm{M} \mathrm{BaCl}_{2}, 0.01 \mathrm{M}$ $\mathrm{BaCl}_{2}$ and $0.01 \mathrm{M} \mathrm{CaCl}$ extractants were not found in the acceptable range for the determination of available Fe in the soil samples.

The concentration of available Fe extracted by EDTA was higher than the concentration extracted by the other universal extractants tested for acidic and neutral soils. This is because of the chelating agent, EDTA; it reduces the activity of the element in soil solution by complexation of the available ions and promoting further dissolution of the solid labile forms of the Fe. This is consistent to the previous research findings [27, 41]. The higher level of available Fe extracted by EDTA could also be due to the higher concentration of the EDTA extractant $(0.026 \mathrm{M})$ as opposed to $0.001 \mathrm{M}$ EDTA in Mehlich 3. Lindsay and Norvell [10] have shown that the amount of nutrient extracted is related to the concentration of chelating agent. 
Evaluation of universal extractants for determination of Selected micronutrients from soil 209

Table 9. Soil available $\mathrm{Fe}\left(\mathrm{mg} \mathrm{kg}^{-1}\right)$ extracted by universal extractants

\begin{tabular}{|l|c|c|c|c|c|c|c|}
\hline Sampling site & \multicolumn{7}{|c|}{ Extractants } \\
\cline { 2 - 8 } & $\begin{array}{c}0.026 \mathrm{M} \\
\text { EDTA }\end{array}$ & $\begin{array}{c}0.01 \mathrm{M} \\
\mathrm{CaCl}_{2}\end{array}$ & $\begin{array}{c}0.01 \mathrm{M} \\
\mathrm{BaCl}_{2}\end{array}$ & $\begin{array}{c}0.02 \mathrm{M} \\
\mathrm{SrCl}_{2}\end{array}$ & $\begin{array}{c}\text { Mehlich } \\
3\end{array}$ & $\begin{array}{c}0.1 \mathrm{M} \\
\mathrm{BaCl}_{2}\end{array}$ & AB-DTPA \\
\hline Damot Sore & $173 \pm 0.2$ & $0.20 \pm 0.1$ & $0.82 \pm 0.01$ & $11.4 \pm 0.5$ & $131 \pm 0.5$ & $1.2 \pm 0.02$ & $26.1 \pm 0.01$ \\
\hline Boloso Bombe & $176 \pm 0.5$ & $0.23 \pm 0.2$ & $0.77 \pm 0.01$ & $11.3 \pm 0.4$ & $140 \pm 0.3$ & $1.4 \pm 0.03$ & $25.5 \pm 0.5$ \\
\hline Damot Pulasa & $191 \pm 1.0$ & $0.30 \pm 0.01$ & $0.32 \pm 0.01$ & $10.8 \pm 0.2$ & $163 \pm 0.2$ & $0.8 \pm 0.01$ & $31.4 \pm 0.5$ \\
\hline Humbo & $181 \pm 0.5$ & $0.33 \pm 0.01$ & $0.73 \pm 0.02$ & $10.4 \pm 0.4$ & $158 \pm 0.2$ & $0.74 \pm 0.01$ & $24.8 \pm 0.2$ \\
\hline Haramaya & $177 \pm 0.5$ & $0.27 \pm 0.01$ & $0.38 \pm 0.01$ & $8.80 \pm 0.02$ & $155 \pm 0.2$ & $0.67 \pm 0.02$ & $17.8 \pm 0.1$ \\
\hline Babile & $86.4 \pm 0.4$ & $0.25 \pm 0.01$ & $0.55 \pm 0.02$ & $8.15 \pm 0.04$ & $91.5 \pm 0.5$ & $0.57 \pm 0.01$ & $5.06 \pm 0.1$ \\
\hline Dire Dawa & $16.4 \pm 0.1$ & $0.16 \pm 0.05$ & $0.26 \pm 0.01$ & $1.46 \pm 0.1$ & $69.3 \pm 0.41$ & $0.34 \pm 0.01$ & $4.2 \pm 0.2$ \\
\hline
\end{tabular}

EDTA = ethylene diamine tetra acetic acid; AB-DTPA = ammonium bicarbonate-diethylene triamine penta acetic acid.

For alkaline soils (Babile District and Dire Dawa Administrative Council), the Mehlich 3 extractant was superior over the other universal extractants tested as shown in Table 9. The higher level of available Fe extracted by Mehlich 3 for alkaline soils might be attributed to the greater acidity of Mehlich 3 and its increased acidic buffering capacity which enhances the solubility of Fe.

The concentration of available Fe extracted by EDTA and Mehlich 3 extractant was higher for acidic and calcareous soils, respectively. The relationship among available Fe extractants was tested for statistical significance. The highest correlation coefficient $(\mathrm{r}=0.95)$ at $(\mathrm{p}<$ 0.001) was found between DTPA and AB-DTPA as shown in Table 8. Therefore, AB-DTPA extractant can replace DTPA extractant for the determination of available $\mathrm{Fe}$ in soils of the studied areas. However, high correlation coefficient $(r=0.75)$ at $(p<0.05)$ was found between DTPA and Mehlich 3.This is consistent with previous research findings [42].

The order of magnitude of extraction of $\mathrm{Cu}$ for Boloso Bombe, Humbo, Babile Districts and Dire Dawa Administrative Council was: $0.02 \mathrm{M} \mathrm{SrCl}_{2}>0.01 \mathrm{M} \mathrm{BaCl}_{2}>0.1 \mathrm{M} \mathrm{BaCl}_{2}>$ EDTA $>$ Mehlich $3>$ AB-DTPA $>0.01 \mathrm{M} \mathrm{CaCl}_{2}$, whereas for Damot Sore and Damot Pulasa Districts the order of magnitude of extraction was: $0.02 \mathrm{M} \mathrm{SrCl}_{2}>0.01 \mathrm{M} \mathrm{BaCl}_{2}>0.1 \mathrm{M} \mathrm{BaCl}_{2}>$ Mehlich $3>$ AB-DTPA $>$ EDTA $>0.01 \mathrm{M} \mathrm{CaCl}_{2}$. On the other hand, the order of magnitude of extraction efficiency for Haramaya District was: EDTA $>$ Mehlich $3>0.02 \mathrm{M} \mathrm{SrCl}_{2}>\mathrm{AB}-$ DTPA $>0.01 \mathrm{M} \mathrm{BaCl}_{2}>0.1 \mathrm{M} \mathrm{BaCl}_{2}>0.01 \mathrm{M} \mathrm{CaCl}_{2}$ (Table 10). The EDTA extractant was shown to be superior to the other extractants tested in this study for the determination of $\mathrm{Cu}$ in soil, particularly for Haramaya District (neutral soil). This could possibly be explained by the high clay content $(26 \%)$ in Haramaya District which enables the EDTA to desorb large portions of $\mathrm{Cu}$ from soil and also due to the greater solubilization effect of the chelating agent, EDTA, for soils with high OM content and high CEC. In addition, in all the studied extractants for the determination of available $\mathrm{Cu}$, the percentage recovery results shown in Table 5 confirms the methods proposed are within acceptable range verifying the validity of the methods for determination of available $\mathrm{Cu}$ in soil samples. The concentration of available $\mathrm{Cu}$ determined by $0.02 \mathrm{M} \mathrm{SrCl}_{2}$ was the highest among the universal extractants tested except for Haramaya District. This is likely due to the strong replacing power of $0.02 \mathrm{M} \mathrm{SrCl}_{2}$ solution to displace $\mathrm{Cu}$ from exchange sites of the soil and the displacement of large portions of $\mathrm{Cu}$ by similar cations. In addition to these, the smaller the hydrated ionic radius, the faster the mobility of the ion in soil solution. That is why $\mathrm{Sr}$ was found to be the most robust in exchanging cations such as $\mathrm{Cu}$ from the soil.

From the data given in Table 8 , it can be shown that the extractants tested for the determination of available $\mathrm{Cu}$ show significant correlation with DTPA method, yet the highest correlation coefficient $(r=0.99)$ at $(\mathrm{p}<0.001)$ was found between DTPA and AB-DTPA. The rest of the methods were also significantly correlated with each other and this is in line with 
several previous findings $[42,43]$. Therefore, AB-DTPA extractant can be considered as suitable extractant for the determination of available $\mathrm{Cu}$ from soil.

Table 10. Soil available $\mathrm{Cu}\left(\mathrm{mg} \mathrm{kg}^{-1}\right)$ extracted by universal extractants.

\begin{tabular}{|l|c|c|c|c|c|c|c|}
\hline \multirow{3}{*}{ Sampling site } & \multicolumn{7}{|c|}{ Extractants } \\
\cline { 2 - 8 } & $\begin{array}{c}0.026 \mathrm{M} \\
\text { EDTA }\end{array}$ & $\begin{array}{c}0.01 \mathrm{M} \\
\mathrm{CaCl}_{2}\end{array}$ & $\begin{array}{c}0.01 \mathrm{M} \\
\mathrm{BaCl}_{2}\end{array}$ & $\begin{array}{c}0.02 \mathrm{M} \\
\mathrm{SrCl}_{2}\end{array}$ & $\begin{array}{c}\text { Mehlich } \\
3\end{array}$ & $\begin{array}{c}0.1 \mathrm{M} \\
\mathrm{BaCl}_{2}\end{array}$ & \begin{tabular}{c} 
AB-DTPA \\
\hline Damot Sore
\end{tabular} \\
\hline Boloso Bombe & $2.82 \pm 0.02$ & $1.40 \pm 0.02$ & $7.34 \pm 0.05$ & $8.85 \pm 0.05$ & $2.41 \pm 0.01$ & $6.14 \pm 0.11$ & $1.95 \pm 0.01$ \\
\hline Damot Pulasa & $2.27 \pm 0.02$ & $2.11 \pm 0.01$ & $8.10 \pm 0.01$ & $9.03 \pm 0.06$ & $3.06 \pm 0.06$ & $3.54 \pm 0.04$ & $2.38 \pm 0.03$ \\
\hline Humbo & $3.14 \pm 0.04$ & $2.07 \pm 0.04$ & $8.02 \pm 0.02$ & $8.82 \pm 0.08$ & $2.91 \pm 0.01$ & $6.14 \pm 0.05$ & $2.15 \pm 0.04$ \\
\hline Haramaya & $19.1 \pm 0.05$ & $3.25 \pm 0.05$ & $8.55 \pm 0.05$ & $9.45 \pm 0.02$ & $9.81 \pm 0.05$ & $6.15 \pm 0.05$ & $8.95 \pm 0.05$ \\
\hline Babile & $3.75 \pm 0.05$ & $1.67 \pm 0.02$ & $7.70 \pm 0.04$ & $8.35 \pm 0.03$ & $3.60 \pm 0.01$ & $5.75 \pm 0.04$ & $2.38 \pm 0.02$ \\
\hline Dire Dawa & $3.65 \pm 0.03$ & $2.15 \pm 0.05$ & $9.73 \pm 0.07$ & $9.11 \pm 0.01$ & $5.14 \pm 0.05$ & $6.45 \pm 0.1$ & $4.48 \pm 0.03$ \\
\hline
\end{tabular}

EDTA $=$ ethylene diamine tetra acetic acid; AB-DTPA = ammonium bicarbonate-diethylene triamine penta acetic acid.

The order of magnitude of extraction of Mn for Damot Pulassa District was: EDTA > Mehlich $3>0.02 \mathrm{M} \mathrm{SrCl}_{2}>0.1 \mathrm{M} \mathrm{BaCl}_{2}>0.01 \mathrm{M} \mathrm{BaCl}_{2}>0.01 \mathrm{M} \mathrm{CaCl}_{2}>$ AB-DTPA (Table 11). However, the order of extraction efficiency was not uniform for the other studied areas. The percentage recovery results for available Mn (Table 6) showed that all the tested extractants were found in the acceptable range for the determination of available $\mathrm{Mn}$ in the soil samples.

Among the universal extractants tested for the determination of available Mn, EDTA extracts the highest amount of Mn than the other tested extractants except soil from Dire Dawa Adminstrative Council. This is possibly due to the chelating effect of EDTA which reduces the activity of the element in soil solution by complexation of the available ions and promoting further dissolution of the solid labile forms of the Mn. In line with these, Lindsay and Norvell [10], Sims and Johnson [12] and Garcia et al. [42] reported that Chelating agents, alone or combined with other solutions, and varying in concentration and $\mathrm{pH}$ level, have been used to estimate available Mn. Similarly, Fisseha [19] found EDTA (pH 8.2) extracting comparatively higher amounts of Mn than DTPA ( $\mathrm{pH} 7.3$ ) extractant. In general, the trend of extraction of available $\mathrm{Fe}$ and $\mathrm{Mn}$ concentrations using different extractants were similar. This implies that these two elements have similar chemical behaviour as described by Kravskof [44].

Table 11. Soil available $\mathrm{Mn}\left(\mathrm{mg} \mathrm{kg}^{-1}\right)$ extracted by universal extractants.

\begin{tabular}{|l|c|c|c|c|c|c|c|}
\hline \multirow{2}{*}{ Sampling site } & \multicolumn{7}{|c|}{ Extractants } \\
\cline { 2 - 8 } & $\begin{array}{c}0.026 \mathrm{M} \\
\text { EDTA }\end{array}$ & $\begin{array}{c}0.01 \mathrm{M} \\
\mathrm{CaCl}_{2}\end{array}$ & $\begin{array}{c}0.01 \mathrm{M} \\
\mathrm{BaCl}_{2}\end{array}$ & $\begin{array}{c}0.02 \mathrm{M} \\
\mathrm{SrCl}_{2}\end{array}$ & $\begin{array}{c}\text { Mehlich } \\
3\end{array}$ & $\begin{array}{c}0.1 \mathrm{M} \\
\mathrm{BaCl}_{2}\end{array}$ & AB-DTPA \\
\hline Damot Sore & $113 \pm 0.5$ & $76.5 \pm 0.5$ & $87.6 \pm 0.4$ & $99.2 \pm 0.2$ & $95.5 \pm 0.3$ & $85.1 \pm 0.1$ & $37.3 \pm 0.3$ \\
\hline Boloso Bombe & $119 \pm 0.4$ & $83.4 \pm 0.1$ & $97.6 \pm 0.2$ & $116 \pm 0.1$ & $119 \pm 0.1$ & $96.2 \pm 0.3$ & $37.6 \pm 0.1$ \\
\hline Damot Pulasa & $112 \pm 0.3$ & $46.8 \pm 0.2$ & $47.3 \pm 0.3$ & $54.5 \pm 0.1$ & $90.3 \pm 0.1$ & $51.3 \pm 0.4$ & $36.4 \pm 0.1$ \\
\hline Humbo & $119 \pm 0.2$ & $60.6 \pm 0.6$ & $18.5 \pm 0.3$ & $25.5 \pm 0.2$ & $113 \pm 0.5$ & $35.9 \pm 0.1$ & $31.3 \pm 0.3$ \\
\hline Haramaya & $118 \pm 0.6$ & $5.51 \pm 0.1$ & $9.60 \pm 0.1$ & $5.40 \pm 0.1$ & $92.6 \pm 0.1$ & $8.80 \pm 0.1$ & $36.2 \pm 0.2$ \\
\hline Babile & $93.5 \pm 0.5$ & $5.07 \pm 0.1$ & $3.21 \pm 0.1$ & $12.8 \pm 0.1$ & $59.4 \pm 0.3$ & $14.9 \pm 0.9$ & $25.3 \pm 0.2$ \\
\hline Dire Dawa & $42.7 \pm 0.2$ & $3.53 \pm 0.3$ & $1.94 \pm 0.2$ & $2.41 \pm 0.3$ & $90.5 \pm 0.4$ & $1.01 \pm 0.1$ & $16.4 \pm 0.2$ \\
\hline
\end{tabular}

EDTA $=$ ethylene diamine tetra acetic acid; AB-DTPA = ammonium bicarbonate-diethylene triamine penta acetic acid.

For alkaline soil (Dire Dawa Administrative Council), the Mehlich 3 extractant was superior to the other universal extractants tested as shown in Table 11. The higher level of available Mn extracted by Mehlich 3 for alkaline soil was attributed to the greater acidity of Mehlich 3 and its increased acidic buffering capacity which enhances the solubility of Mn. 
The concentration of available Mn extracted by EDTA and Mehlich 3 extractants was higher for acidic and alkaline soils, respectively. The relationship among available Mn extractants was tested for statistical significance. The highest correlation coefficient $(r=0.90)$ at $(p<0.01)$ was found between $0.01 \mathrm{M} \mathrm{CaCl}_{2}$ and DTPA extractants as shown in Table 8. Similarly, high correlation coefficients $(\mathrm{r}=0.85)$ at $(\mathrm{p}<0.05)$ was found between DTPA and AB-DTPA. The strong correlation coefficient between Mehlich 3 and DTPA $(r=0.75)$ was supported by previous study [45]. Although significant correlation was observed between $0.01 \mathrm{M} \mathrm{CaCl}_{2}$ and the DTPA extractant, the AB-DTPA extractant could easily be adopted for the determination of $\mathrm{Mn}$ in soil considering the use of universal extractant.

Table 12. Soil available $\mathrm{Zn}\left(\mathrm{mg} \mathrm{kg}^{-1}\right)$ extracted by universal extractants.

\begin{tabular}{|l|c|c|c|c|c|c|c|}
\hline Sampling site & \multicolumn{7}{|c|}{ Extractants } \\
\cline { 2 - 8 } & $\begin{array}{c}0.026 \mathrm{M} \\
\text { EDTA }\end{array}$ & $\begin{array}{c}0.01 \mathrm{M} \\
\mathrm{CaCl}_{2}\end{array}$ & $0.01 \mathrm{M} \mathrm{BaCl}_{2}$ & $\begin{array}{c}0.02 \mathrm{M} \\
\mathrm{SrCl}_{2}\end{array}$ & $\begin{array}{c}\text { Mehlich } \\
3\end{array}$ & $\begin{array}{c}0.1 \mathrm{M} \\
\mathrm{BaCl}_{2}\end{array}$ & AB-DTPA \\
\hline Damot Sore & $12.4 \pm 0.1$ & $3.70 \pm 0.03$ & $6.60 \pm 0.03$ & $6.30 \pm 0.03$ & $2.90 \pm 0.02$ & $6.37 \pm 0.1$ & $6.34 \pm 0.1$ \\
\hline Boloso Bombe & $24.6 \pm 0.02$ & $6.30 \pm 0.07$ & $10.7 \pm 0.02$ & $10.7 \pm 0.02$ & $8.70 \pm 0.04$ & $8.80 \pm 0.08$ & $9.90 \pm 0.04$ \\
\hline Damot Pulasa & $13.1 \pm 0.05$ & $4.10 \pm 0.05$ & $4.10 \pm 0.06$ & $2.90 \pm 0.01$ & $3.70 \pm 0.03$ & $3.50 \pm 0.04$ & $6.70 \pm 0.05$ \\
\hline Humbo & $31.4 \pm 0.02$ & $7.90 \pm 0.02$ & $3.40 \pm 0.02$ & $2.30 \pm 0.01$ & $12.2 \pm 0.02$ & $1.40 \pm 0.02$ & $9.40 \pm 0.04$ \\
\hline Haramaya & $5.10 \pm 0.1$ & $0.31 \pm 0.01$ & $2.10 \pm 0.05$ & $1.60 \pm 0.02$ & $0.61 \pm 0.01$ & $0.45 \pm 0.1$ & $1.30 \pm 0.02$ \\
\hline Babile & $3.66 \pm 0.03$ & $0.21 \pm 0.01$ & $1.90 \pm 0.02$ & $1.50 \pm 0.03$ & $0.34 \pm 0.01$ & $0.70 \pm 0.01$ & $0.78 \pm 0.02$ \\
\hline Dire Dawa & $6.30 \pm 0.02$ & $0.51 \pm 0.02$ & $1.50 \pm 0.01$ & $1.10 \pm 0.03$ & $2.20 \pm 0.01$ & $1.90 \pm 0.06$ & $2.30 \pm 0.03$ \\
\hline
\end{tabular}

$\mathrm{EDTA}=$ ethylene diamine tetra acetic acid; AB-DTPA = ammonium bicarbonate-diethylene triamine penta acetic acid.

Among the universal extractants tested for the determination of available $\mathrm{Zn}$, the highest concentration was determined by EDTA extractant for all soil samples in the studied areas (Table 12) and this is in line with several previous research findings [11, 46]. The highest concentration of available $\mathrm{Zn}$ extracted by EDTA could be explained to its strong chelating agent capable of forming complexation and decreases adsorption of $\mathrm{Zn}$ on the clay particles and results in increasing the solubility of $\mathrm{Zn}^{2+}$ in soils. The order of magnitude of available $\mathrm{Zn}$ extraction differed according to the soil types and extractants used. This is due to the fact that $\mathrm{Zn}$ had been reported to be generally of low mobility in soils [47] and has a tendency of being adsorbed on clay sized particles [48]. The percentage recovery results for available $\mathrm{Zn}$ (Table 6) showed that all the tested extractants were found in the acceptable range for the determination of available $\mathrm{Zn}$ in the soil samples of the studied areas.

From the data given in Table 8 , it can be shown that the extractants tested for the determination of available $\mathrm{Zn}$ show significant correlation with DTPA method, yet the highest correlation coefficient $(r=0.97)$ at $(\mathrm{p}<0.001)$ was found between DTPA and AB-DTPA. The rest of the methods were also significantly correlated with each other and this is in contrast with previous findings [42]. Therefore, AB-DTPA extractant can be considered as suitable extractant for the determination of available $\mathrm{Zn}$ for soil of the studied areas.

\section{CONCLUSIONS}

This study has shown that among the seven universal extractants tested for the determination of available Fe, EDTA and Mehlich 3 extracted large amount for acidic and basic soils respectively. However, the highest correlation coefficient $(r=0.95)$ at $(p<0.001)$ was found between DTPA and AB-DTPA. Therefore, AB-DTPA extractant can replace DTPA extractant for the determination of available Fe.

For the determination of available $\mathrm{Cu}$, the $0.02 \mathrm{M} \mathrm{SrCl}_{2}$ universal extractant extracts high amount in all soil samples except for neutral soil. However, the highest correlation coefficient ( $\mathrm{r}$ 
$=0.99)$ at $(\mathrm{p}<0.001)$ was found between DTPA and AB-DTPA. Therefore, AB-DTPA extractant can be considered as suitable extractant for the determination of available $\mathrm{Cu}$ for soil of the studied areas.

Among the universal extractants tested for the determination of available Mn, EDTA extracts the highest amount of Mn than the other tested extractants except in soil from Dire Dawa Administrative Council. However, better correlations were observed among DTPA, 0.01 $\mathrm{M} \mathrm{CaCl}_{2}$, and AB-DTPA though the correlation was higher in the case of $0.01 \mathrm{M} \mathrm{CaCl}_{2}$. Hence, AB-DTPA extractant can easily be adopted for the determination of available $\mathrm{Mn}$ in soils of the studied areas given the efficiency of this extractant for the other analytes as well.

Although EDTA extracts the highest concentration of available $\mathrm{Zn}$, the highest correlation coefficient $(\mathrm{r}=0.97)$ at $(\mathrm{p}<0.001)$ was found between DTPA and AB-DTPA. Therefore, ABDTPA extractant can be considered as suitable extractant for the determination of available $\mathrm{Zn}$ for soil of the studied areas. Generally, the AB-DTPA extractant is considered to be the best for the determination of available $\mathrm{Fe}, \mathrm{Cu}, \mathrm{Mn}$ and $\mathrm{Zn}$ in soils.

\section{ACKNOWLEDGMENT}

This work was financially supported by Ministry of Education and Wolaita Sodo University. We thus acknowledge these institutions and the staff members of Soil Chemistry Laboratory, Haramaya University and staff members of Ethiopian Geological Survey, Addis Ababa, for providing us with the necessary supports to conduct this study.

\section{REFERENCES}

1. Fageria, N.K. J. Plant Nutr. 2007, 30, 203.

2. Maqueda, C; Herenci, J.F.; Ruiz, J.C.; Hidalgo, M.F. J. Agric. Sci. 2011, 149, 461.

3. Ibrahim, A.K.; Abubakar, B. Asian J. Agric. Food Sci. 2013, 1, 217.

4. Portch, S.; Stauffer, M.D. J. Crops. 2005, 89, 28.

5. Haby, V.A.; Russele, M.P.; Skogley, E.O. Westerman, R.L. Soil Testing and Plant Analysis, 3rd ed., Soil Science Society of America: Wisconsin, USA; 1990; p 181.

6. McLaughlin, M.J.; Lancaster, P.A.; Sale, P.W.G.; Uren, N.C.; Peverill, K.I. Plant and Soil. 1993, 155, 223.

7. Ayodele, O.J.; Omotoso S.O.; Agboola, A.A. Int. Res. J. Agric. Sci. Soil Sci. 2013, 3, 416.

8. Jones, J.B. Commun. Soil Sci. Plant Anal. 1998, 29, 1543.

9. Ranger, C.B. Anal. Chem. 1981, 53: 20.

10. Lindsay, W.L.; Norvell W.A. Soil Sci. Soc. Am. J. 1978, 42, 421.

11. Mehlich, A. Commun. Soil Sci. Plant Anal. 1984, 15, 1409.

12. Sims, J.T.; Johnson, C.V. Micronutrient Soil Tests, 2nd ed., Soil Science Society of America: Wisconsin, USA; 1991; p 427.

13. Wang, J.J.; Harrell, D.L.; Henderson, R.E.; Bell, P.F. Commun. Soil Sci. Plant Anal. 2004, 35,145 .

14. Boon, D.Y.; Soltanpour, P.N. Commun. Soil Sci. Plant Anal. 1991, 22, 369.

15. Alva, A.K. Commun. Soil Sci. Plant Anal. 1992, 23, 2493.

16. Bortolon, L.; Gianello, C. Braz. J. Soil 2009, 33, 647.

17. Asgelil, D.; Taye, B.;Yesuf, A. Proceedings of Agric. Research Fund, Ethiopia; 2007; 77.

18. Desta, B. Soil Sci. Bull. Ethiop. 1982, 4, 43.

19. Fisseha, I. Macro and Micronutrient Distributions in Ethiopian Vertisol Landscapes, PhD Thesis, University of Hohenheim, Germany; 1992.

20. Teklu, B.; Amnat, S.; Yongyuth, O.; Sarobol, E.D. Kasetsart, J. Nat. Sci. 2007, 41, 84. 
Evaluation of universal extractants for determination of Selected micronutrients from soil 213

21. Gizaw, B. Report on Waterman Workshop, Haramaya University, Ethiopia; 2006.

22. WZFEDD Socio- Economic Information of Wolaita Zone, 2012.

23. DDA (Dire Dawa Administration) Program of Adaptation to Climate Change, 2011.

24. Van Loon, J.C.; Parissis, C.M. Analyst 1969, 94, 1057.

25. Ekosse, G.I.; Stella, A. Bull. Chem. Soc. Ethiop. 2012, 26, 373.

26. Van Reeuwijk, L.P. Procedures for Soil Analysis, 3rd ed., Wageningen: The Netherlands; 1992.

27. Norvell, W.A. Soil Sci. Society Am. J. 1984, 48, 1285.

28. Salmon, E. Commun. Soil Sci. Plant Anal. 1998, 29, 2841.

29. Simard, R.R.; Tran, T.S.; Zizka, J. Soil Sci. Society Am. J. 1991, 55, 414.

30. Li, L.; Zhank, J.; Xing, W.; Cheu, W.; Wu, X.; Zhu, K. Commun. Soil Sci. Plant Anal. 2006, $37,1627$.

31. Soltanpour, P.N.; Schwab, A.P. Commun. Soil Sci. Plant Anal. 1977, 8, 195.

32. Meseret, A.; Negussie, M.; Abi, M.T.; Tesfa, B. Toxicol. Environ. Chem. 2013, 95, 82.

33. Michael, Y.; Chandravanshi, B.S.; Tadesse, W. J. Food Chem. 2008, 107, 1236.

34. Winefordner, J.D.; Somenoth, M. Sample Preparation Techniques in Analytical Chemistry, 2nd ed., John Willey and Sons Inc: New Jersey; 2003.

35. SAS (Statistical Analysis System) Institute, Inc., Cary, N.C.; 2004.

36. Donald, L. Environmental Soil Chemistry, 2nd ed., University of Delaware, Academic Press: An imprint of Elsevier Sciences; 2003; p 367.

37. Minilu, D.; Chandravanshi, B.S. Bull. Chem. Soc. Ethiop. 2011, 25, 169.

38. Atlabachew, M.; Chandravanshi, B.S.; Redi, M. Trends Applied Sci. Res. 2011, 6, 640.

39. Enwezor, W.O.; Udo, E.J.; Ayotade, K.A.; Adepetu, J.A.; Chude, V.O. A Review of Soil and Fertilizer Use in Nigeria, Federal Ministry of Agriculture and Natural Resources, Lagos; 1990; p 241.

40. Havlin J.L.; Beaton, J.D.; Tisdale, S.L.; Nelson, W.L. Soil Fertility and Fertilizers, 6th ed., Prentice Hall: New Jersely; 1999.

41. Abreu, C.A.; Raij, B.V.; Abreu, M.F.; Santos, W.R.; Andrade, J.C. Commun. Soil Sci. Plant Anal. 1996, 27, 763.

42. Garcia, A.A.; Iorio, F.D.; Barros, M.; Bargiela, M.; Rendina, A. Commun. Soil Sci. Plant Anal. 1997, 28, 1777.

43. Wendt, J.W. Commun. Soil Sci. Plant Anal. 1995, 26, 687.

44. Kravskof, K.B. Soil Sci. Soc. Am. Proceeding, Madison, Wisconsin, USA; 1972.

45. Vocasek, F.F.; Friedericks, J.B. Commun. Soil Sci. Plant Anal. 1994, 25, 1583.

46. Rohman, P.C.; Cox, F.R. Commun. Soil Sci. Plant Anal. 1988, 19, 1859.

47. Chesworth, W. Geochemistry of Micronutrients, 2nd ed., Soil Science Society of America: Wisconsin, USA; 1991; $\mathrm{p} 427$.

48. Alloway, B.J. Zinc in Soils and Crop Nutrition. International Fertilizer Industry Association: Brussels, Belgium; 2008. 